\title{
Community preferences for the preservation of Canary Palm from Red Palm Weevil in the city of Bari
}

\author{
Ruggiero Sardaro ${ }^{1}$, Luigi Roselli ${ }^{1}$, Rinaldo Grittani ${ }^{1}$, Maria Scrascia ${ }^{2}$, Carlo Pazzani ${ }^{2}$, Valentina Russo ${ }^{3}$, \\ Francesca Garganese ${ }^{3}$, Carlo Porfido ${ }^{3}$, Laura Diana ${ }^{4}$, Francesco Porcelli ${ }^{3,4^{*}}$ \\ (1) Department of Agricultural and Environmental Science, University of Bari Aldo Moro, 70126 Bari, Italy, \\ Email: ruggiero.sardaro1 @ uniba.it; (2) Department of Biology, University of Bari Aldo Moro, 70126 Bari, Italy; \\ (3) CIHEAM IAM Mediterranean Agronomic Institute of Bari, 70010 Valenzano, Italy; (4) Department of Soil, \\ Plant and Food Sciences, University of Bari Aldo Moro, 70126 Bari, Italy.
}

\begin{abstract}
Sardaro, R., L. Roselli, R. Grittani, M. Scrascia, C. Pazzani, V. Russo, F. Garganese, C. Porfido, L. Diana and F. Porcelli. 2019. Community preferences for the preservation of Canary Palm from Red Palm Weevil in the city of Bari. Arab Journal of Plant Protection, 37(2): 206-211.

Rhynchophorus ferrugineus (red palm weevil) caused the death of $40 \%$ of Phoenix canariensis Chabaud (Canary palm) between 2011 and 2013 in the city of Bari. Extraordinary measures of compulsory pest control at EU and national level were applied, which however require public funds, hence proper cost-benefit studies, in order to favour better decision-making for urban green management. In this work, we investigated the preferences of the urban community towards specific measures for the preservation of Canary palm through a choice experiment. The results can be used to endorse the strategy in force and to shed light on effective and efficient prospective expenditures of public funds for areas affected by red palm weevil.

Keywords: Rhynchophorus ferrugineus, Phoenix canariensis Chabaud, Community preferences, Choice experiments, Apulia.
\end{abstract}

\section{Introduction}

The international trade of palms has increased the risk of introduction of Rhynchophorus ferrugineus (Olivier, 1790), namely the red palm weevil (RPW), in Italy. The presence of RPW in the country concerns the infestations of Phoenix canariensis Chabaud, the Canary palm, in the coastal regions and islands, causing the death of numerous plants. Nowadays, this phenomenon increases the risk of extinction of Canary palm in the urban centres, and jeopardizes a distinctive landscape characteristic of the Italian coastal areas. In this regard, the Canary palm in the city of Bari is an important element of the urban flora, especially in the historic area. However, RPW caused the death of $40 \%$ of these trees between 2011 and 2013, risking to modify definitively the urban landscape (Sardaro et al., 2018), a key element of individual and social welfare (Council of Europe, 2000).

In order to contain the impact of RPW, extraordinary measures of compulsory pest control at the European Union and national level (European Commission's decision 2007/365/CE and ministerial decree of 7 February 2011) were defined. In particular, these measures concern specific regulations for the trade of Canary palms in the national territory, as well as interventions on time and intensity of pruning, pest control and sanitation. However, at urban scale, such actions require public funds, hence proper cost-benefit studies, in order to favour better decision-making for urban green management (Bradley, 1995), is badly needed.

http://dx.doi.org/10.22268/AJPP-037.2.206211

(C) 2019 Arab Society for Plant Protection الجمعية العربية لوقاية النبات
This study investigated the interest of the urban community in the city of Bari towards Canary palm, and shed light on the best suitable management and preservation measures to contain the impact of RPW, so as to preserve the urban landscape (Sardaro et al., 2017a, 2017b). The findings can also be used to endorse the preservation strategy in force (i.e. pest control only in the historic urban area), since uncertainty involves a wide share of decision makers and dwellers about the expenditure of public funds for this urban tree species.

\section{Material and Methods}

The questionnaire and the survey design

A choice experiment (CE) involving the urban dwellers in the city of Bari was carried out. This research method is a stated preference approach based on conjoint analysis and discrete choice theory (Louviere et al., 2000; Train, 2009), and defines hypothetical scenarios by choice tasks, properly selected from all the possible ones according to statistical designs. Each choice task consists of alternatives, made of different combinations of characteristics (attributes) of Canary palms and respective levels. Therefore, for each choice task, respondents choose the preferred alternative, i.e. the one that gives the greatest relative utility, in order to reveal their preference (Hensher et al., 2015). The aim is the assessment of the importance that respondents place on each attribute.

The questionnaire consisted of three sections. The first contained questions aimed at understanding general 
preferences of respondents toward Canary palms as an element of urban green. The second section, based on the choice sets (Table 1), investigated the importance that respondents gave to some characteristics (attributes) of the urban Canary palms, namely:

a) Management plan, concerning the preservation of the current number of Canary palms in the city of Bari or their doubling through new trees;

b) Urban district, referred to the desired urban area in which the preservation of Canary palms should be strengthened;

c) Arrangement, about the desired spatial arrangement of Canary palms;

d) Urban furniture, regarding the desired urban components which Canary palms should decorate, in particular natural components (urban gardens, parks, etc.), transport components (roads), historic components (historic areas and monuments), sociocultural components (schools, university, aggregation places, etc.) and institutional components (public buildings of municipal, regional, and security authorities);

e) Monetary contribution for the management of the urban Canary palms concerning the annual payment required by the urban households for the preservation of the current trees or even for new plantations, in addition to pest control, pruning, etc. for the coming 10 years.

These attributes and respective levels were selected through two focus group constituted by dwellers (4), nurserymen (2), municipal technicians (2), and university scholars (1).

Finally, the third section of the questionnaire included socio-demographic questions. Prior to conducting the survey, a pre-test was carried out based on a random sample of 21 respondents in order to verify the consistency and comprehensibility of the questions. The face-to-face interviews were addressed to adult citizens of Bari, lasted each around 30 minutes, and were carried out between December 2017 and July 2018.

Concerning the choice's alternatives, among the 1,080 possible combinations $\left(2^{1} \times 3^{1} \times 4^{1} \times 5^{1} \times 9^{1}\right)$, forty were selected by an orthogonal experimental design in order to construct 20 choice sets (Table 2), divided into two blocks of ten, so that each respondent was randomly given to one block. Finally, the survey was based on 700 interviews (350 per block), and carried out through a convenience sampling procedure.

Table 1. Attributes and levels used in the survey.

\begin{tabular}{ll}
\hline Attribute & Levels \\
\hline Management Plan & Current No. of Canary Palms, Doubling the No. of Canary Palms \\
Urban district & 1 - Palese/Santo Spirito, 2 - San Paolo/Stanic, \\
& 3 - Picone/Poggiofranco, 4 - Carbonara/Ceglie/Loseto, \\
& 5 - Japigia/Torre a Mare, 6 - Carrassi/San Pasquale, \\
& 7 - Madonnella, 8 - Libertà/Marconi/San Girolamo Fesca, \\
& - San Nicola/Murat
\end{tabular}

Spatial arrangement

Urban furniture

Monetary contribute for the management of the urban Canary Palms (yearly payment for a ten-year period)
Isolated trees, Group trees, Road trees

Natural components, Transport components, Historic components, Sociocultural components, Institutional components

$5 € / y r, 10 € / y r, 20 € / y r, 50 € / y r$

Table 2. Example of choice set used in the survey.

\begin{tabular}{llll}
\hline Attribute & Option A & Option B & No option \\
\hline Management Plan & Current Canary Palms & Doubling of Canary Palms & Neither A nor B. \\
Urban district & San Nicola - Murat & Japigia - Torre a Mare & $\begin{array}{l}\text { I do not want to } \\
\text { participate to the } \\
\text { municipal preservation } \\
\text { plan for Canary Palms }\end{array}$ \\
Urbatial arrangement & Isolated trees & Grouped trees & \\
Monetary contribute & Sociocultural components & Natural components & $5 € /$ yr \\
What Option do you prefer? & $20 € / y r$ & & \\
\hline
\end{tabular}




\section{The statistical method used}

The CE assumes that the preference among the alternatives is defined by the utility of respondents. In particular, considering an individual choosing the alternative that can guarantee the greatest utility among the possible alternatives for a given choice $t$, the utility function is given by the following expression (Train, 2009):

$$
U_{i j t}=V_{i j t}+e_{i j t}, \quad i=1, \ldots, I ; \quad j=1, \ldots, J ; \quad t=1, \ldots, T
$$

where $V_{i j t}$ is the deterministic component, and $e_{i j t}$ is the casual component, independently and identically distributed (IID). Assuming a linear utility function in the parameters for the deterministic component, the expression (1) can be reformulated as:

$$
U_{i j t}=\boldsymbol{\beta}_{i}^{\prime} \mathbf{x}_{i j t}+\varepsilon_{i j t}, \quad i=1, \ldots, I ; \quad j=1, \ldots, J ; \quad t=1, \ldots, T
$$

where $\boldsymbol{\beta}_{\mathrm{i}}$ is a $K \times 1$ vector of parameters to estimate, concerning utility and referred to $K$ characteristics of choice, while $x_{i j t}$ is the $K \times 1$ vector of the characteristics of choice regarding the alternative $j$ for the occasion of choice $t$ by the respondent $i$. The expression (2) introduces a specific vector $\boldsymbol{\beta}_{\mathrm{i}}$ for respondents, with distribution $\mathrm{g}(\boldsymbol{\beta} \mid \boldsymbol{\theta})$, for which the vector $\boldsymbol{\theta}$ indicates mean and variance. This specification allows relaxing the IID assumption, and is the base of the random parameter logit model (RPLM). It catches the heterogeneity of non-observed factors, which are common to groups of respondents and can influence their behaviour, hence their decisional process.

The conditional probability on the $\beta_{i}$ parameters, for which a respondent $i$ chooses o sequence of choices $s_{i}=\left\{s_{i l}\right.$, $\left.s_{i 2}, \ldots, s_{i T}\right\}$, given the profiles $x_{i}=\left\{x_{i 1}, x_{i 2}, \ldots, x_{i T}\right\}$, is:

$$
P\left(s_{i} \mid x_{i}, \boldsymbol{\beta}\right)=\prod_{t=1}^{T}\left[\frac{\exp \left(\boldsymbol{\beta}_{i}^{\prime} \mathbf{x}_{i s_{i t} t}\right)}{\sum_{j=1}^{J} \exp \left(\boldsymbol{\beta}_{i}^{\prime} \mathbf{x}_{i j t}\right)}\right]
$$

By integrating the expression (3) as to the distribution of $\boldsymbol{\beta}$, the unconditioned probability is:

$$
P\left(s_{i} \mid x_{i}, \boldsymbol{\theta}\right)=\int_{\beta} P\left(s_{i} \mid x_{i}, \boldsymbol{\beta}\right) g(\boldsymbol{\beta} \mid \boldsymbol{\theta}) d \boldsymbol{\beta}
$$

Expression (4) has not a closed solution, thus simulated methods of maximum likelihood were carried out (Onazaka and McFadden, 2011). The Halton method based on 100 extractions was used (Bhat, 2003; Train, 2009), as well as a triangular and normal distribution for the functional form of the density functions of parameters (Greene and Hensher, 2003). The willingness to pay (WTP) was calculated through the delta method.

\section{Results}

The socio-demographics of the respondents in the sample were congruent with the characteristics of the reference population (city of Bari), indicating a good reliability of the estimates (Table 3).
Table 3. Main socio-demographics of the respondents.

\begin{tabular}{llcc}
\hline & Variable & $\begin{array}{c}\text { Respondents } \\
(\boldsymbol{\%})\end{array}$ & $\begin{array}{c}\text { Population } \\
\text { characteristics } \\
(\mathbf{\%})\end{array}$ \\
\hline Gender & Male & 51.6 & 47.9 \\
& Female & 48.4 & 52.1 \\
Age & $18-30$ & 19.6 & \\
(years) & $31-50$ & 36.0 & 14.1 \\
& $51-78$ & 44.4 & 36.3 \\
Marital & Unmarried & 46.3 & 49.6 \\
status & Married & 53.7 & 40.2 \\
\hline
\end{tabular}

* Istat, 2016.

For the RPLM (Table 4), the choice of the random parameters, based on Hensher et al. (2015), was affected considering the significance of the standard deviations from different RPLMs based on various sets of parameters (Vecchiato and Tempesta, 2013). The significant and negative alternative-specific constant (ASC) indicated a general willingness to participate in the municipal preservation plan for Canary palms in the city of Bari. Moreover, the main preference of dwellers was related to their general willingness to preserve the current number of Canary palms, and to a lesser extent to double them. Noteworthy were the results concerning the preferences based on the districts in which the preservation of Canary palms should be strengthened. In particular, the respondents preferred the suburban (Palese/Santo Spirito, Japigia/Torre a Mare, San Paolo/Stanic, Libertà/Marconi/San Girolamo Fesca, Madonnella) and central (San Nicola/Murat) districts, mainly located along the urban coastal area, whereas less interest or aversion was expressed for the semi central and inner districts. These findings in part supported the preservation strategy in force promoted by the municipal authorities, concerning the implementation of a pest control only in the central historic urban area, in part suggest a necessary enforcement of the same strategy by focusing also on the suburban and coastal districts, often characterized by infrastructural and social abandonment and degradation. Hence, the dwellers of the city of Bari desire better suburban environments, also in aesthetic terms, and the preservation of Canary palms in these areas is considered as one of the possible strategies that municipal authorities should carry out. The second important aspect emerging through the analysis concerns the type of urban furniture for which Canary palm should be used. The respondents preferred this tree species mainly in natural areas (gardens and parks) and along urban roads, followed by the historic and sociocultural components, while were indifferent towards the institutional areas. Finally, the dwellers pointed out interest towards the spatial arrangement of these trees, so that road and group Canary palms were preferred, compared to the isolated plants. 
Table 4. The random parameters logit model (RPLM) and willing to pay (WTP) results obtained.

\begin{tabular}{|c|c|c|c|c|c|}
\hline Attribute & Levels & Coefficient & \multicolumn{2}{|c|}{ Standard } & WTP \\
\hline \multicolumn{6}{|c|}{ Random parameters in utility functions } \\
\hline \multirow[t]{2}{*}{ Management Plan } & Current Canary Palms & 2.4772 & $* * *$ & 0.3445 & 48.39 \\
\hline & Doubling of Canary Palms & 0.3662 & $* *$ & 0.1294 & 4.72 \\
\hline \multirow[t]{9}{*}{ Urban areas } & Palese/Santo Spirito & 1.1832 & $* * *$ & 0.1586 & 20.16 \\
\hline & Japigia/Torre a Mare & 1.1952 & $* * *$ & 0.1985 & 23.01 \\
\hline & San Paolo/Stanic & 0.7607 & $* * *$ & 0.2341 & 14.80 \\
\hline & Libertà/Marconi/San Girolamo Fesca & 0.6005 & **** & 0.1041 & 9.57 \\
\hline & Madonnella & 0.1339 & $*$ & 0.0644 & 2.36 \\
\hline & Carrassi/San Pasquale & -0.3270 & & 0.2819 & \\
\hline & Picone/Poggiofranco & 0.5451 & & 0.3922 & \\
\hline & Carbonara/Ceglie/Loseto & -0.2628 & $* *$ & 0.1173 & -5.32 \\
\hline & San Nicola/Murat & 1.4557 & $* * *$ & 0.2292 & 24.28 \\
\hline \multirow[t]{3}{*}{ Spatial arrangement } & Road trees & 0.3535 & $* * *$ & 0.0517 & 4.56 \\
\hline & Group trees & 0.2163 & $* * *$ & 0.0424 & 3.19 \\
\hline & Isolated trees & -0.4920 & $* *$ & 0.2130 & -6.85 \\
\hline \multirow[t]{5}{*}{ Urban furniture } & Natural components & 0.7350 & $* *$ & 0.3182 & 14.20 \\
\hline & Transport components & 0.7256 & $* * *$ & 0.1012 & 11.64 \\
\hline & Historic components & 0.5814 & $* * *$ & 0.0908 & 9.32 \\
\hline & Sociocultural components & 0.3172 & $* *$ & 0.1350 & 4.86 \\
\hline & Institutional components & 0.3921 & & 0.0587 & \\
\hline \multicolumn{2}{|l|}{ Monetary contribute } & -0.0534 & $* * *$ & 0.0083 & \\
\hline \multicolumn{6}{|c|}{ Nonrandom parameters in utility functions } \\
\hline \multicolumn{2}{|c|}{ ASC } & -1.7384 & ** & 0.7067 & \\
\hline \multicolumn{2}{|l|}{ Pseudo R-squared } & 0.3508 & & & \\
\hline \multicolumn{2}{|c|}{ Obs. } & 6260 & & & \\
\hline \multicolumn{2}{|c|}{ Log likelihood function } & -5613.40 & & & \\
\hline
\end{tabular}

Overall, the respondents of the city of Bari were particularly interested to the implementation of a management strategy for Canary palms based on the preservation of the current number of these plants by focusing on road and group trees accompanying natural, transport and historic components in the central and coastal districts. The WTPs related to the significant attributes/levels were calculated, so that the respondents were willing to pay, on average, a monetary contribute of $48 € /$ year/household, for 10 years, in order to preserve the actual Canary palms in the city of Bari, and from 2 to $24 €$ /year/household, for 10 years, depending on the urban district in which the preservation plan should be strengthened (Figure 1). Moreover, a monetary contribute from 5 to 14 $€ /$ year/household, for 10 years, was also expressed depending on the type of urban furniture, and from 3 to 5 $€ /$ year/household, for 10 years, according to the type of spatial arrangement of Canary palms.

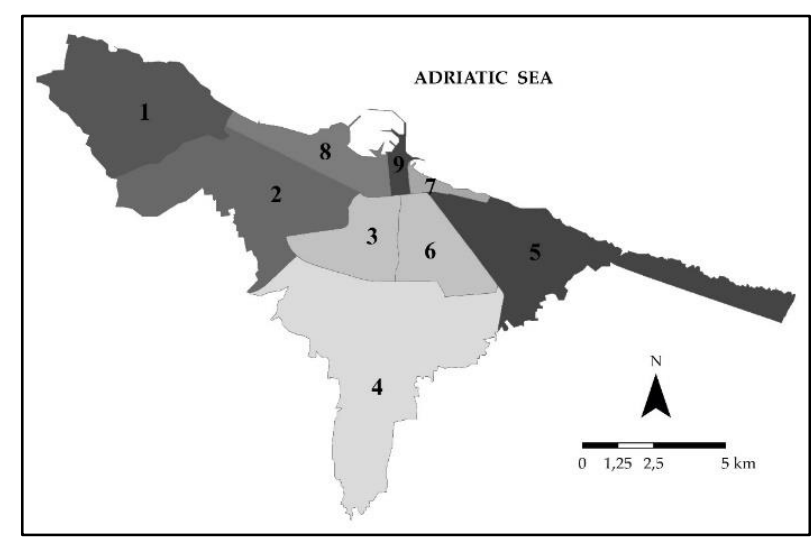

Figure 1. WTP per district of the City of Bari. 


\section{Discussion}

Urban green, with its multifunctional aspects, is one of the most important elements influencing the quality of life in cities (Marinelli and Marone, 2013). In recent years, there has been a growing interest about its evaluation, both for the quantification of possible damages and for the implementation of policies aimed at its management. This study pointed out that the CE method is a useful approach for the analysis of community's preferences about possible characteristics of preservation policies based on more effective and efficient measures against RPW. In addition, understanding if the community is in favour of the preservation of Canary palms is very useful in order to detect optimal management and preservation plan of urban green based on public funds. Indeed, as pointed out by the European Landscape Convention (Council of Europe, 2000) and the Millennium Ecosystem Assessment (MEA, 2005), the carried-out approach fosters bottom-up, transparent and fair decision-making by involving the main beneficiary of urban green, i.e., the dwellers, in order to facilitate urban development policies (Petrillo and Sardaro, 2014; Sardaro et al., 2015).

\footnotetext{
الملخص

ساردارو، روجيرو، ليوجي روزيللي، رينالدو غريتاني، ماريا سكراسيا، كارلو بازّاني، فالنتينا روسّو، فرانسيسكا غارغنس، كارلو بورفيدو، لورا ديانا وفرانسيسكو بورسيللي. 2019. تفضيلات المجتمع المحلّي للحفاظ عل نخيل الكناري من سوسة النخيل الحمراء في مدينة باري. مجلة وقاية النبات العربية، 37(2): 206-211.

تسبّبت سـوسـة النخيل الحمراء Rhynchophorus ferrugineus Olivier بموت 40\% من أشـجار نخيل الكناري Phoenix canariensis Chabaud ما بين عامي 2011 و 2013 في مدينة باري. وقد طبّتت تدابير اســتنائية للمكافحة الإلزامية للآفة في دول الاتحاد الأوروبي وعلى المســتوى الوطني؛ الأمر الذي يتطلّب

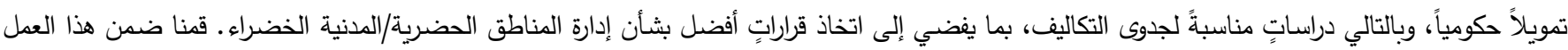
باستقصـاء تفضيلات المجتمع المدني بثأن اتخاذ إجراءات محدّدة لصيانة أثجار نخيل الكناري وذلك من خلال تجربة الاختيار . وبمكن استخدام نتائج هذه الدراسـة

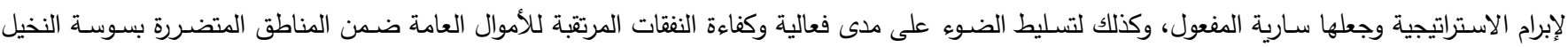
الحمراء. كلمات مفتاحية: Phoenix canariensis Chabaud Rhynchophorus ferrugineus، تفضيلات المجتمع المحلي، تجارب الاختيار، منطقة بوليا.
}

\section{References}

Bhat, C. 2003. Simulation estimation of mixed discrete choice models using randomized and scrambled Halton sequences. Transportation Research Part B Methodological, 37: 837-855. https://doi.org/10.1016/S0191-2615(02)00090-5

Bradley, G.A. 1995. Urban Forest Landscapes: Integrating Multidisciplinary Perspectives. University of Washington Press, Seattle, WA, USA. 224 pp.

Council of Europe. 2000. European Landscape Convention. Council of Europe, Strasbourg, France.

Greene, W.H. and D.A. Hensher. 2003. A latent class model for discrete choice analysis: contrasts with mixed logit. Transportation Resource Part B Methodological, 37: 681-698. https://doi.org/10.1016/S0191-2615(02)00046-2

Hensher, D.A., J.M. Rose and W.H. Greene. 2015. Applied choice analysis. 2nd edition. Cambridge University Press, Cambridge. 1216 pp.

Louviere, J.J., D.A. Hensher and J.D. Swait. 2000. Stated choice methods: analysis and applications. Cambridge University Press, Cambridge. 420 pp.

Marinelli, A. and E. Marone. 2013. Il valore economico totale dei boschi della Toscana. Franco Angeli, Milano, Italy. 147 pp.
MEA - Millennium Ecosystem Assessment. 2005. Ecosystems and Human Well-being: A Framework for Assessment. Available online: https://millenniumassessment.org/en/Framework.html (accessed on January 2019).

Onazaka, Y. and D.T. McFadden. 2011. Does local labeling complement or compete with other sustainable labels? A conjoint analysis of direct and joint values for fresh produce claims. American Journal of Agricultural Economics, 93: 689-702. https://doi.org/10.1093/ajae/aar005

Petrillo, F. and R. Sardaro. 2014. Urbanizzazione in chiave neoliberale e progetti di sviluppo a grande scala. Scienze Regionali, 13: 125-134. https://doi.org/10.3280/SCRE2014-002010

Sardaro, R., V. Fucilli and C. Acciani. 2015. Measuring the value of rural landscape in support of preservation policies. Scienze Regionali, 14: 125-138.

Sardaro, R., R. Grittani, M. Scrascia, C. Pazzani, V. Russo, F. Garganese, C. Porfido, L. Diana and F. Porcelli. 2018. The red palm weevil in the city of Bari: A first damage assessment. Forests, 9: 452. https://doi.org/10.3390/f9080452 
Sardaro, R., D. Panio, V. Fucilli, F. Bozzo and C. Acciani. 2017a. The ornamental value of trees and choice experiments: a further methodological approach. Aestimum, 70: 75-95.

https://doi.org/10.13128/Aestimum-21082

Sardaro, R., E. Pieragostini, G. Rubino and F. Petazzi. 2017b. Impact of Mycobacterium avium subspecies paratuberculosis on profit efficiency in semi-extensive dairy sheep and goat farms of Apulia, southern Italy. Preventive Veterinary Medicine, 136: 56-64. https://doi.org/10.1016/j.prevetmed.2016.11.013
Train, K.E. 2009. Discrete choice methods with simulation. 2nd edition. Cambridge University Press, Cambridge. 400 pp.

Vecchiato, D. and T. Tempesta. 2013. Valuing the benefits of an afforestation project in a peri-urban area with choice experiments. Forest Policy and Economics, 26: 111-120.

https://doi.org/10.1016/j.forpol.2012.10.001 